In day 1 cow colostrum neutralising antibody titres to human rotavirus ranged from 400 to 6400 while the IgA and IgG content was $23-170 \mathrm{mg} / \mathrm{dl}$ and $1500-4200 \mathrm{mg} / \mathrm{dl}$, respectively. Both titres and Ig concentrations were lower in colostrum from days 2 and 3. Market milk contained little IgA or IgG and few neutralising antibodies. Because the human jejunum contains $200 \mu \mathrm{g} / \mathrm{ml}$ trypsin we treated colostrum samples with trypsin $(100-800 \mu \mathrm{g} / \mathrm{ml})$ for $1 \mathrm{~h}$ at $37^{\circ} \mathrm{C}$ : rotavirus neutralising titres were not affected.

In the therapeutic trial rota colostrum had no effect on duration of diarrhoea, bowel movements, or virus shedding in stool. However, there were no side-effects of rota colostrum-in particular, no milk allergy.

6 orphans were given $20 \mathrm{ml}$ rota colostrum (titre 400-1280) every morning. Of the 9 controls, given $20 \mathrm{ml}$ of market milk, 2, who had had diarrhoea in 1981, were already seropositive for rotavirus and were excluded from the statistical analysis. In Tsuruoka city, sporadic cases of acute gastroenteritis were reported in midDecember, 1982, so rota colostrum (or milk) prophylaxis was started in the orphanage on Dec 14. On Jan 26 there was an outbreak of rotavirus diarrhoea at the orphanage, affecting 6 of the 7 controls but only 1 of the 6 infants given rota colostrum $(p<0 \cdot 05)$. All 13 infants had fever but influenza $A$ virus was prevalent in the orphanage at the time.

5 infants given rota colostrum had paired complement fixation tests for rotavirus antibody before and after the epidemic of diarrhoea. Sera were negative (titre $<4$ ) in all 5 before the epidemic. 2 infants who escaped diarrhoea showed rises in antibody titre after the epidemic, suggesting that rota colostrum causes natural inapparent rotavirus infection but prevents the onset of diarrhoea.

Rota colostrum seems to be an effective and safe measure for preventing diarrhoea caused by rotavirus infection.

We thank Dr Natsume Yazaki, Dr Michiyo Sakamoto, Dr Yoshio Okuyama, and Dr Kayoko Hori (Yamagata City Hospital, Saiseikan) and the nurses at Tsuruoka Orphanage. This work was supported in part by a grant from the Sendai Institute of Microbiology.

\begin{tabular}{|c|c|c|}
\hline \multirow{7}{*}{$\begin{array}{l}\text { Department of Bacteriolo } \\
\text { and Paediatrics, } \\
\text { Tohoku University Schor } \\
\text { Sanda 980, Japan; } \\
\text { Yamagata Prefectural Ins } \\
\text { of Public Health, } \\
\text { and Yamagata City Ho }\end{array}$} & T. EBINA & A. SATO \\
\hline & K. UMEZU & N. IsHIDA \\
\hline & S. OHYAMA & A. OHIZumI \\
\hline & K. AIKAWA & S. KATAGIRI \\
\hline & N. Katsushima & A. IMAI \\
\hline & S. KITAOKA & H. SUZUKI \\
\hline & & \\
\hline
\end{tabular}

\section{ADULT T-CELL LEUKAEMIA WITH SPONTANEOUS REMISSION}

SIR, -Few cases of adult T-cell lymphoma-leukaemia (ATL) have been reported from the United States. ${ }^{1}$ We describe here a case with antibodies to human T-cell lymphoma virus (HTLV) in which there was spontaneous remission without evidence of residual leukaemia at necropsy.

A 73-year-old White man from Michigan was admitted to the University of Michigan Hospital because of altered mental status. He had enlarged inguinal lymph nodes, a serum calcium of $17 \cdot 1$ $\mathrm{mg} / \mathrm{dl}$, and a white blood cell (WCC) count of $20400 \times 10^{9} / 1$ with $44 \%$ lymphocytes. With hydration and steroid therapy, the serum calcium fell to normal over 4 days and the inguinal lymphadenopathy disappeared. The WCC rose to $32800 \times 10^{9} / 1$ with $68 \%$ lymphocytes, $75 \%$ of which had multilobulated nuclei (figure). Less than $10 \%$ abnormal lymphocytes were detected in a bone marrow smear. Skin lesions were absent. ATL was suspected. The WCC fell to $20400 \times 10^{9} / 1$ with $80 \%$ lymphocytes, and during the following weeks returned to normal with only occasional lobulated lymphocytes.

Cell surface antigen phenotyping ('EPICS V' flow cytometer; Coulter Electronics) revealed that more than $80 \%$ of peripheral blood lymphocytes had the phenotype $\mathrm{T} 11+, \mathrm{T} 3+, \mathrm{T} 4, \mathrm{~T} 10+$. Aneuploidy was not detected. $70 \%$ of these cells were $\mathrm{T} 4+$ (helper/inducer) and 26\% were T8+ (suppressor/cytotoxic). The $\mathrm{T} 4+$ and $\mathrm{T} 8+$ subpopulations were tested for human interleukin-2

1. Bunn PA, Schecter GP, Jaffe E, et al. Clinical courses of retrovirus-associated adult T-cell lymphoma in the United States. $N$ Engl f Med 1983; 309: 257-64.
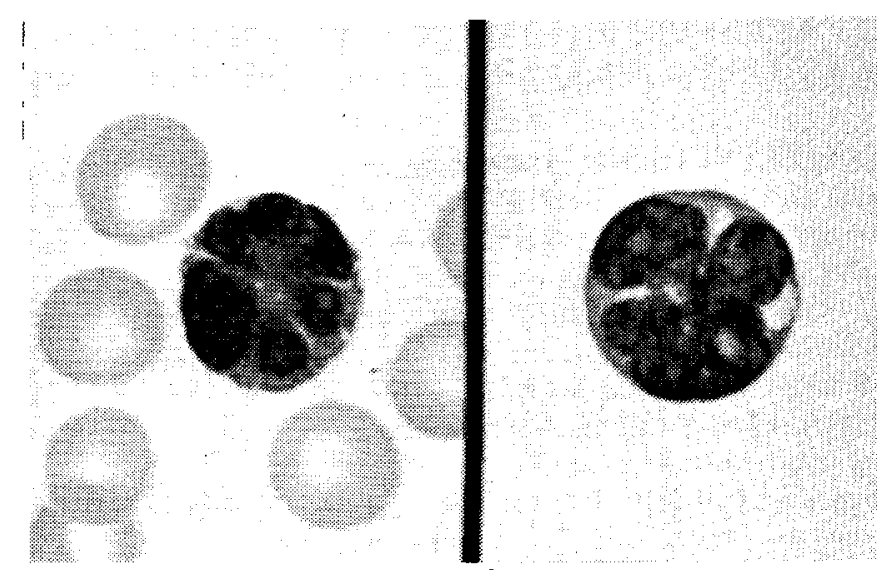

Multilobulated lymphocytes.

Left: peripheral blood. Right: sorted Tac-positive cell (Wright's stain, $\times 600$ )

receptor with the anti-Tac monoclonal antibody. ${ }^{2,3}$ This receptor is not present on circulating lymphocytes or monocytes, but is present on circulating cells from Japanese patients with ATL. ${ }^{4}$ In our patient $33 \%$ of lymphocytes were Tac + and all of these cells bore the T4 antigen. None of the T8 + cells were Tac + . Both the T4+ $\mathrm{Tac}+$ and the $\mathrm{T} 8+\mathrm{Tac}-$ populations were sorted and examined morphologically (figure). The Tac + cells had diffuse granular acid phosphatase activity and multilobulated nuclei; the $\mathrm{T} 8+$ cells appeared normal. Examination of cytocentrifuge preparations of several pleural and abdominal fluids also revealed the presence of multilobulated lymphocytes. No definite evidence of lymphoma was detected at necropsy, although on careful examination of lymph nodes, scattered lymphocytes with lobulated nuclei were seen. Scalloping of trabecular bone with increased osteoclasts was evident. The cause of death (6 weeks after onset of illness) was cytomegalovirus pneumonia.

Although the hypercalcaemia, absolute lymphocytosis with $\mathrm{T} 4+$ Tac + multilobulated lymphocytes in the blood, lymphadenopathy, and antibodies to HTLV suggested that the patient had ATL, no evidence of neoplasm was present post mortem despite the fact that no chemotherapy had been given.
Department of Pathology

University of Michigan

Ann Arbor, Michigan 48109 , USA
BERTRAM SCHNITZER EDMUND J. LOVETT, III LARRY E. KAHN

\section{INHALED SALBUTAMOL: A NEW FORM OF DRUG ABUSE?}

SiR,-While looking after asthmatic children at Sheffield Children's Hospital, I have noticed several adolescents who, given a salbutamol inhaler, abuse it and take bigger and bigger doses more and more often. Often they admit to taking the inhaler not only when they are wheezy but also when they "feel the need" and are tense and anxious. In at least five cases they or their parents have expressed great concern at this "addiction".

Even more disturbing are other reports I have had. One from a patient was of salbutamol inhalers being freely available for $£ 1$ each in a flat frequented by young people not known to be asthmatic, but who do indulge in glue-sniffing. Another was from a medical student who saw some teenagers passing an inhaler round the group at a local disco. Also a school nurse reported that a non-asthmatic boy had been caught using salbutamol 'Rotacaps' because he said it made him feel "good".

Hyperactivity and a manic mood are well recognised side-effects of oral salbutamol in young children, and an antidepressant effect of

2. Uchiyama T, Broder $S$, Waldman TA. A monoclonal antibody (ant1-Tac) reactive with activated and functionally mature human $T$ cells $I$ : Production of anti-Tac monoclonal antibody and distribution of Tac $(+)$ cells. F Immunol 1981; 126: monoclonal

3. Leonard WJ, Depper JM, Uchiyama T, et al. A monoclonal antibody that appears to recognize the receptor for human $T$ cell growth factor: Partial characterization of the receptor Nature 1982; 300: 267-69.

4. Uchyyama T, Nelson DL, Fleisher TA, Waldmann TA. A monoclonal antibody (antrTac) reactive with activated and functionally mature human $T$ cells II: Expression of Tac antigen on activated cytotoxic killer cells, suppressor cells, and on one of two types of helper cells. Immunol 1981; 126: 1398-1403 